\title{
Isolation and antibacterial activity of diffractic acid compound from lichen Usnea blepharea Motyka
}

\author{
Maulidiyah Maulidiyah* (D), Muhammad Natsir, Wa Nazila, Andi Musdalifah, La Ode Agus Salim (iD, Muhammad Nurdin (D) \\ Department of Chemistry, Faculty of Mathematics and Natural Sciences, Universitas Halu Oleo, Kendari, Indonesia.
}

\begin{tabular}{l}
\hline ARTICLE INFO \\
\hline Received on: 07/06/2021 \\
Accepted on: 14/08/2021 \\
Available online: 03/11/2021 \\
\\
\hline Key words: \\
Lichen U. blepharea Motyka, \\
diffractic acid, antibacterial, \\
S. aureus, E. coli.
\end{tabular}

\section{INTRODUCTION}

The wealth of biological natural resources from lichen organisms is widely used for traditional and herbal medicine. Lichen is a symbiotic organism between fungi and algae or cyanobacteria (Maulidiyah et al., 2021b). Generally, these organisms are found in tree trunks, soil, rocks, shorelines, and mountain cliffs. Lichen is divided into three groups, namely crustose, foliose, and fruticose (Lumbsch, 2020). The mutualistic symbiosis of lichen has the potential to produce secondary metabolites for medicines of natural origin or as raw materials for the pharmaceutical industry. One of the several genera of fruticose

\section{"Corresponding Author}

Maulidiyah Maulidiyah, Department of Chemistry, Faculty of Mathematics and Natural Sciences, Universitas Halu Oleo, Kendari, Indonesia.

E-mail:maulid06@yahoo.com is Usnea. Several types of lichen from the genus Usnea that have been widely used as traditional medicines are the species $U$. articulate, U. dasypoga, U. longissima, U. sternaii, U. vrieseana, U. comosa, U. blepharea, U. baileyi, U. javanica, and U. flexuosa (Dini et al., 2017; Maulidiyah et al., 2011; Sepahvand et al., 2020).

Secondary metabolites in Usnea sp. include benzofuran, depside, depsidone, benzyl ester, xanthone, aliphatic, and lactone groups (Huneck and Yoshimura, 1996). Several previous studies have reported various biological activities of lichen Usnea, including as an antiproliferative (Mitrovic et al., 2011), antibiotic (Shrestha and Clair, 2013), antifungal (Yu et al., 2016), anticancer (Zugic et al., 2016), antimalarial (Pamenta et al., 2020), antibacterial (Maulidiyah et al., 2020b; Siddiqi et al., 2018), antidiabetic (Maulidiyah et al., 2020a), and antioxidant (Maulidiyah et al., 2021a) agent. The use of lichen Usnea in the healthcare sector, especially medicinal substances, is related to the substances contained therein. Based on Kosanic and Rankovic's (2015) study, lichen has been used to treat diseases caused 
by the bacteria Staphylococcus aureus and Escherichia coli. Staphylococcus aureus has infected many humans, especially the mucosa of the nasal area, upper respiratory tract, gastrointestinal tract, and skin. Escherichia coli bacteria also can cause infections in the human digestive tract such as diarrhea (Karve et al., 2017).

Bacteria can be inhibited by secondary metabolites of lichen, such as lauric acid compounds from Usnea barbata (Rankovic et al., 2012), a usnic acid compound from U. longissima (Maulidiyah et al., 2016a), a protolichesterinic acid compound from Usnea albopunctata (Sasidharan et al., 2014), and atranorin from Usnea rubrotincta (Sasidharan et al., 2014). According to Sudarwanti et al. (2018), the acetone extract is more effective at inhibiting bacterial growth because it contains various types of secondary metabolite compounds such as flavonoids, alkaloids, tannins, and terpenoids. Some probable antibacterial mechanisms of lichen substances are inhibition of protein and nucleic acid synthesis, cell membrane alteration, cell wall, and inhibition of metabolism (Rankovic and Kosanic, 2019).

Overall, only a few lichens have been studied for their chemical content and biological activity and many have not been exploited, especially lichen $U$. blepharea Motyka. Lichen $U$. blepharea Motyka is a specific lichen that we have been studying in recent years. This lichen is an endemic lichen that grows in the mountainous region of Sulawesi, Indonesia. Several secondary metabolites have been reported for this species, including usnic acid (Maulidiyah et al., 2015a) and eumitrin A1 (Maulidiyah et al., 2015b). As another novelty of this study, we specifically studied the characteristics of the secondary metabolite obtained, namely diffractic acid. This has not been carried out before by other researchers.

\section{EXPERIMENTAL METHOD}

\section{Materials}

One of the materials used in this research is a sample of lichen U. blepharea Motyka which was obtained from Mount Bawakaraeng, Malino, Gowa Regency, South Sulawesi, Indonesia. Acetone, n-hexane, ethyl acetate, dichloromethane, chloroform, diethyl ether, ethanol, glacial acetic acid, deuteriochloroform, $95 \%$ ethanol, distilled water, dimethyl sulfoxide, $\mathrm{H}_{2} \mathrm{SO}_{4} 10 \%$ in methanol, chloramphenicol (Bernofarm), and amoxicillin (Bernofarm) were obtained from Sigma-Aldrich. Nutrient agar, peptone $0.5 \%$, agarose $3 \%$, beef extract, $\mathrm{NaCl}$, and $\mathrm{BaCl}_{2}$ were obtained from Merck, Germany. Other materials used were silica gel 60 (Merck 7732) for column chromatography, silica gel 60 F254 no. 1.05554.0001 for aluminum and glass thin-layer chromatography (TLC) plates (Merck), and bacteria: E. coli and S. aureus.

\section{Isolation of secondary metabolite from lichen $\mathrm{U}$. blepharea Motyka}

Lichen U. blepharea Motyka in powder as much as $500 \mathrm{~g}$ was extracted continuously using Soxhlet with an acetone solvent for 8 hours till a crude extract of acetone was obtained. The crude extract of acetone was evaporated in a vacuum rotary evaporator. Furthermore, the dry extract was tested using TLC with a plate size of $1 \times 4 \mathrm{~cm}$ to determine the composition of the solvent that gave the best separation. The TLC plate was sprayed with a stain of $10 \% \mathrm{H}_{2} \mathrm{SO}_{4}$ solution in methanol. The dry extract was separated by gravity column chromatography (GCC) with a column size of $50 \mathrm{ml}$ and a diameter of $2 \mathrm{~cm}$. The preparation of GCC was carried out by the stationary phase of $60 \mathrm{G}$ silica gel eluted with a mixed solvent of n-hexane and ethyl acetate in a gradient. Each eluted was collected every $60-100 \mathrm{ml}$ and these were grouped based on the similarity of the stain spots in TLC. The almost pure fraction was purified based on differences in polarity in the solvent, while the impure fraction was refined using column chromatography and preparative TLC.

\section{Identification of the isolate structure}

The structure of the pure isolates obtained was a determined compound using 1D-nuclear magnetic resonance [(NMR) $\left({ }^{1} \mathrm{H}\right.$ and $\left.\left.{ }^{13} \mathrm{C}\right)\right]$ (JEOL JNM ECA 500), Fourier-transform infrared spectroscopy (FTIR) (Shimadzu IRAffinity-1S system), UV-Vis spectrophotometer (UV 3150 Shimadzu Corp., Japan), and liquid chromatography-mass spectrophotometer (LC-MS) (LCMS 8060 System). Based on the spectroscopic measurements data, each molecular structure was determined by comparing each spectrum with data from the literature and database (ChemOffice) and based on the basic theory of spectroscopy.

\section{Antibacterial inhibitory activity test}

Antibacterial activity was tested by the diffusion method using the well technique (Oh et al., 2018). The first stage was making the base of the test media using $10 \mathrm{ml}$ nutrient agar (NA) media, which was poured into a sterile Petri dish and then left for 15 minutes until it became solid. After the solid NA media solidified, six anchors were placed as a mold for holes or wells. Semisolid media were prepared and homogenized by mixing 200 $\mu \mathrm{l}$ of bacterial suspension into $10 \mathrm{ml}$ of liquefied NA media in a test tube. Semisolid media were poured into the Petri dish around the storage device and allowed to solidify. The backup tool was then removed using sterile tweezers to form a hole (well). A total of $30 \mu \mathrm{l}$ of test isolate samples was dropped into the well with various concentrations of $1,000,750,500,100,50$, and $25 \mathrm{ppm}$, respectively, followed by positive and negative controls. The positive control used 1,000 ppm chloramphenicol and amoxicillin, while the negative control used distilled water and acetone. Petri dishes containing the test compound were put into an incubator at $37^{\circ} \mathrm{C}$ for 24 hours. The results of the antibacterial power test are based on measuring the diameter of the inhibition area formed around the well hole.

\section{RESULTS AND DISCUSSION}

\section{Isolation of lichen U. blepharea Motyka}

Isolation and purification produced isolate compounds in the form of white needle crystals, with a melting point of $190^{\circ} \mathrm{C}-191^{\circ} \mathrm{C}$, which dissolved in chloroform and acetone. Based on the liquid chromatography (LC) data, the high-intensity chromatogram (T2.4) showed the purity of the obtained isolated compound (Fig. 1A). This was confirmed by another chromatogram with a small intensity. Based on the mass spectrometry (MS) data of the isolate compounds (Fig. 1B), the compound with the addition of hydrogen shows the peak of the molecular ion $[\mathrm{M}+\mathrm{H}]^{+}$ at $m / z=375.09$ and indicates a molecular weight of $[\mathrm{M}]^{+}=374.09$. Based on the report of Huneck and Yoshimura (1996), a melting point with a range of $190^{\circ} \mathrm{C}-191^{\circ} \mathrm{C}$ and a molecular weight of 

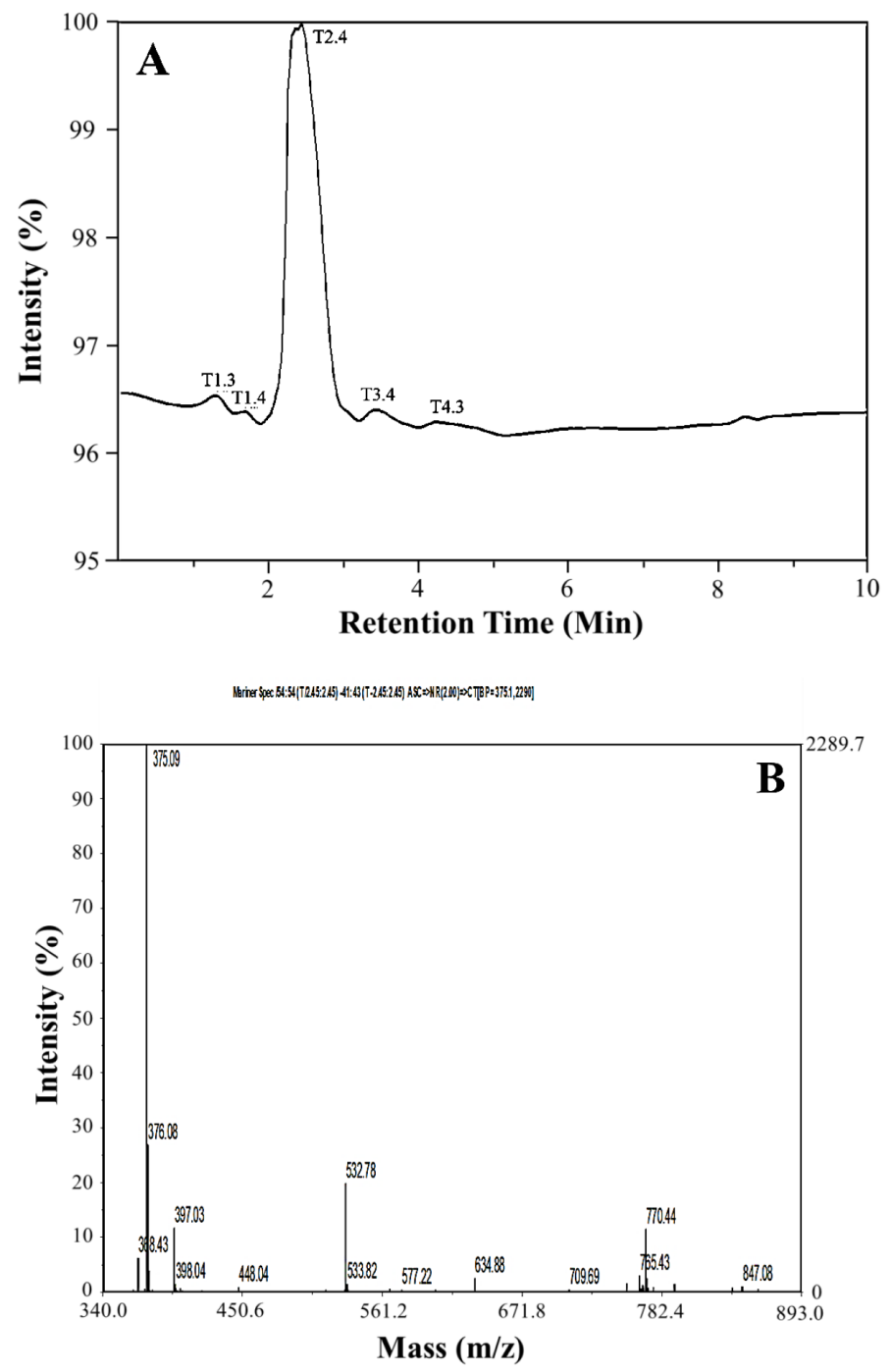

Figure 1. Chromatogram of data measurement. (A) LC and (B) MS.

$[\mathrm{M}]^{+}=374$ indicates a diffractic acid compound $\left(\mathrm{C}_{20} \mathrm{H}_{22} \mathrm{O}_{7}\right)$. To strengthen this assumption, we continue to interpret the UV-Vis spectrophotometer, FTIR, and NMR data.

The UV-Vis spectroscopic data of the isolates were measured at a wavelength of $\lambda=300-500 \mathrm{~nm}$ in an acetone solvent which gave maximum absorption at a wavelength of $\lambda_{\max }=324$ nm (Fig. 2). Based on a study of the literature, this wavelength describes two electronic transition states for isolates, namely the $n \rightarrow \pi^{*}$ transition originating from the carbonyl group and the $\pi \rightarrow \pi^{*}$ transition originating from the benzene ring and carbon bond. This situation is strengthened by the high absorption intensity (Abid et al., 2017; Bayir et al., 2006; Belay and Gholap, 2009). Determination of the functional groups of isolated compounds used FTIR (Fig. 3). The FTIR spectrum of the isolate compound obtained the absorption band in the region of wavenumber $(v)$ $3,726 \mathrm{~cm}^{-1}$ indicating the presence of an $\mathrm{OH}$ group; the absorption band at wavenumber $2,954 \mathrm{~cm}^{-1}$ is the asymmetric stretching vibration $\mathrm{C}-\mathrm{H}$. The presence of an absorption band at wavenumber $1,735 \mathrm{~cm}^{-1}$ is the vibration of the carbonyl group, while the absorption band at wavenumber $1,612 \mathrm{~cm}^{-1}$ is the vibration of the $\mathrm{C}=\mathrm{C}$ bond from aromatics. Furthermore, the absorption band of
$1,134 \mathrm{~cm}^{-1}$ indicates the presence of $\mathrm{C}-\mathrm{O}-\mathrm{C}$ bonds. Based on the FTIR spectrum data, it can be estimated that the isolate compound has a hydroxy group $(-\mathrm{OH})$, a carbonyl group $(\mathrm{C}=\mathrm{O})$, an aromatic group, and a $\mathrm{CH}_{3}$ group.

Based on the ${ }^{1} \mathrm{H}-\mathrm{NMR}$ spectrum, Figure 4 and Table 1 show the presence of two methoxy groups, namely the chemical shifts $\delta_{\mathrm{H}}=3.83 \mathrm{ppm}(3 \mathrm{H}, \mathrm{s})$ and $3.89 \mathrm{ppm}(3 \mathrm{H}, \mathrm{s}) . \delta_{\mathrm{H}}=6.67 \mathrm{ppm}$ $(1 \mathrm{H}, \mathrm{s})$ and $6.75 \mathrm{ppm}(1 \mathrm{H}, \mathrm{s})$ indicate the presence of two protons, each bound to the aromatic and isolated rings. The presence of four singlet methyl groups is seen in the chemical shifts $\delta=2.13$ ppm $(3 \mathrm{H}, \mathrm{s}), 2.12 \mathrm{ppm}(3 \mathrm{H}, \mathrm{s}), 2.44 \mathrm{ppm}(3 \mathrm{H}, \mathrm{s})$, and $2.61 \mathrm{ppm}$ $(3 \mathrm{H}, \mathrm{s})$.

The ${ }^{13} \mathrm{C}$-NMR spectrum (Fig. 5) accompanied by distortionless enhancement by polarization transfer (DEPT) (Fig. 6A) shows that the compound contains 20 carbon atoms consisting of 4 methyl groups, 2 methoxy groups, 2 methine groups, and 12 quaternary atoms. Four methyl groups are seen at $\delta_{\mathrm{C}}=9.11,9.36,20.04$, and $24.01 \mathrm{ppm}$. Two methoxy groups were seen at $\mathrm{C}=56.25 \mathrm{ppm}$ and $62.39 \mathrm{ppm}$. Two methine $(\mathrm{CH})$ groups were seen at $\delta_{\mathrm{C}}=117.18$ and $109.10 \mathrm{ppm}$. The chemical shift $\mathrm{C}=166.54$ and $174.36 \mathrm{ppm}$ is the carbon of the carbonyl group. Chemical shifts $\delta_{\mathrm{C}}=110.33,117.85,120.92,136.05$, 141.13 , and $160.92 \mathrm{ppm}$ are quaternary olefinic carbon; $\delta_{\mathrm{C}}=$ $154.44,157.89,160.92$, and $164.07 \mathrm{ppm}$ are quaternary carbons bonded to oxygen atoms. The ${ }^{13} \mathrm{C}-\mathrm{NMR}$ data is supported by the ${ }^{1} \mathrm{H}-\mathrm{NMR}$ data.

${ }^{13} \mathrm{C}$-NMR data show that there are two carbons which are carbons of the carbonyl group. This is reinforced by the FTIR spectrum data at a wavenumber of $1,735 \mathrm{~cm}^{-1}$. A wavenumber of $1,134 \mathrm{~cm}^{-1}$ indicates the presence of $\mathrm{C}-\mathrm{O}-\mathrm{C}$ bonds strengthening the presence of carbon bonded to oxygen atoms. Based on comparing the spectroscopic data from the isolate compound with the compounds in the literature, the isolate compound was very similar to the diffractic acid compound. This is reinforced by the heteronuclear multiple quantum correlation (HMQC) spectrum (Fig. 6B). It can be seen that the position of C- $8^{1}\left(\delta_{\mathrm{C}}=9.11 \mathrm{ppm}\right)$ correlates with protons $\delta_{\mathrm{H}}=2.12 \mathrm{ppm}$. The position of C-8 $8^{1}\left(\delta_{\mathrm{C}}\right.$ $=9.36 \mathrm{ppm})$ correlated with protons $\mathrm{H}=2.13 \mathrm{ppm}, \mathrm{C}-9\left(\delta_{\mathrm{C}}=\right.$ $20.04 \mathrm{ppm})$ correlated with protons $\delta_{\mathrm{H}}=2.44 \mathrm{ppm}, \mathrm{C}-91\left(\delta_{\mathrm{C}}=\right.$ $24.01 \mathrm{ppm})$ correlated with protons $\mathrm{H}=2.61 \mathrm{ppm}, \mathrm{C}-2-\mathrm{OCH}_{3}\left(\delta_{\mathrm{C}}\right.$ $=62.39 \mathrm{ppm})$ correlated with protons $\delta_{\mathrm{H}}=3.83 \mathrm{ppm}, \mathrm{C}-4-\mathrm{OCH}_{3}$ $\left(\delta_{\mathrm{C}}=56.25 \mathrm{ppm}\right)$ correlated with protons $\delta_{\mathrm{H}}=3.89 \mathrm{ppm}, \mathrm{C}-5\left(\delta_{\mathrm{C}}=\right.$ $109.10 \mathrm{ppm})$ correlated with protons $\delta_{\mathrm{H}}=6.75 \mathrm{ppm}$, and C- $5^{1}\left(\delta_{\mathrm{C}}\right.$ $=117.18 \mathrm{ppm})$ correlated with protons $\delta_{\mathrm{H}}=6.67 \mathrm{ppm}$.

Based on correlated spectroscopy (COSY) (Fig. 6C), a proton with a chemical shift $\delta_{\mathrm{H}}=2.61 \mathrm{ppm}$ correlates with a proton $\delta_{\mathrm{H}}=6.67 \mathrm{ppm}$. Protons $\delta_{\mathrm{H}}=2.44 \mathrm{ppm}$ correlated with protons $\delta_{\mathrm{H}} \mathrm{H}$ $=6.75 \mathrm{ppm}$. Protons $\delta_{\mathrm{H}}=3.89 \mathrm{ppm}$ correlated with protons $\delta_{\mathrm{H}}=6.75$ ppm. A proton with $\mathrm{H}=3.83 \mathrm{ppm}$ a proton with $\mathrm{H}=2.12 \mathrm{ppm}$. The heteronuclear multiple bond correlation (HMBC) (Fig. 6D) shows the correlation between proton $\mathrm{H}-5$ at $\delta_{\mathrm{H}}=6.75$ (s) and carbon C-4 $\left(\delta_{\mathrm{C}}=160.91\right)$, C-9 $\left(\delta_{\mathrm{C}}=20.04\right)$, and C-3 $\left(\delta_{\mathrm{C}}=120.92\right)$. Proton H-5 at $\delta_{\mathrm{H}}=6.67(\mathrm{~s})$ correlated with carbon C-4 $4^{\mathrm{1}}\left(\delta_{\mathrm{C}}=154.44\right), \mathrm{C}-31\left(\delta_{\mathrm{C}}\right.$ $=117.52), \mathrm{C}-11\left(\delta_{\mathrm{C}}=110.33\right)$, and $\mathrm{C}-91\left(\delta_{\mathrm{C}}=24.01\right)$. Proton $\mathrm{H}-8$ at $\delta_{\mathrm{H}}=2.12(\mathrm{~s})$ correlated with carbon $\mathrm{C}-4\left(\delta_{\mathrm{C}}=160.92\right)$ and $\mathrm{C}-2$ $\left(\delta_{\mathrm{C}}=157.89\right)$. Proton $\mathrm{H}-9$ at $\delta_{\mathrm{H}}=2.44$ (s) correlated with carbons C-1 $\left(\delta_{\mathrm{C}}=117.85\right), \mathrm{C}-6\left(\delta_{\mathrm{C}}=136.05\right)$, and C-5 $\left(\delta_{\mathrm{C}}=109.11\right)$. The proton $\delta_{\mathrm{H}}-8^{1}$ is at $\mathrm{H}=2.13$ with carbons $\mathrm{C}-2^{1}\left(\delta_{\mathrm{C}}=164.06\right), \mathrm{C}-5^{1}\left(\delta_{\mathrm{C}}\right.$ 


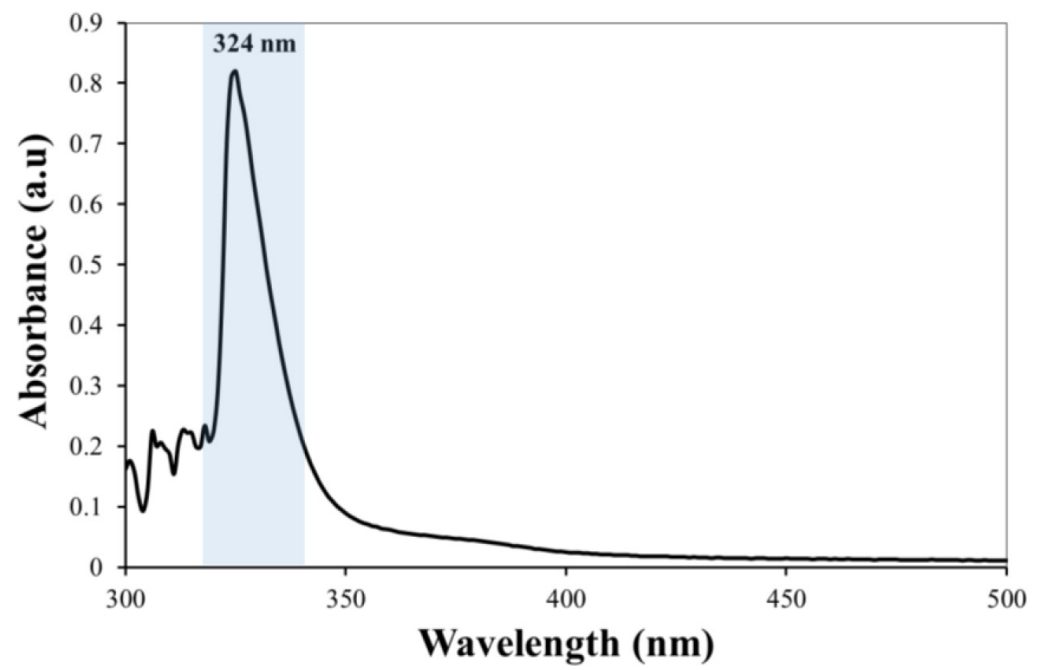

Figure 2. UV-Vis spectroscopic data of isolate compound.

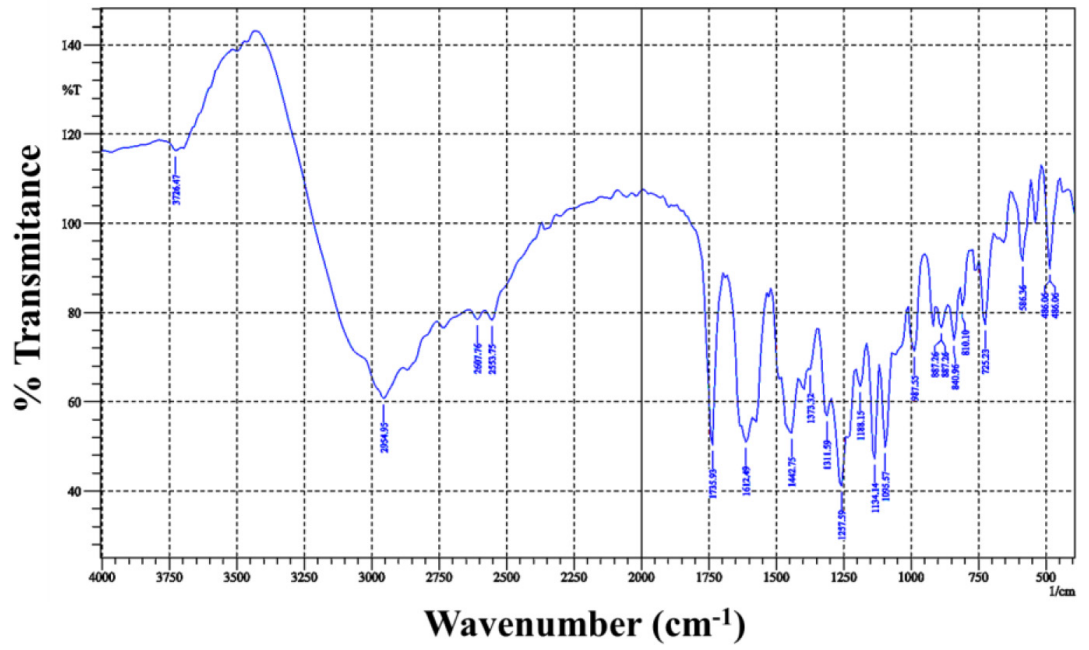

Figure 3. FTIR spectrum of isolate compounds.

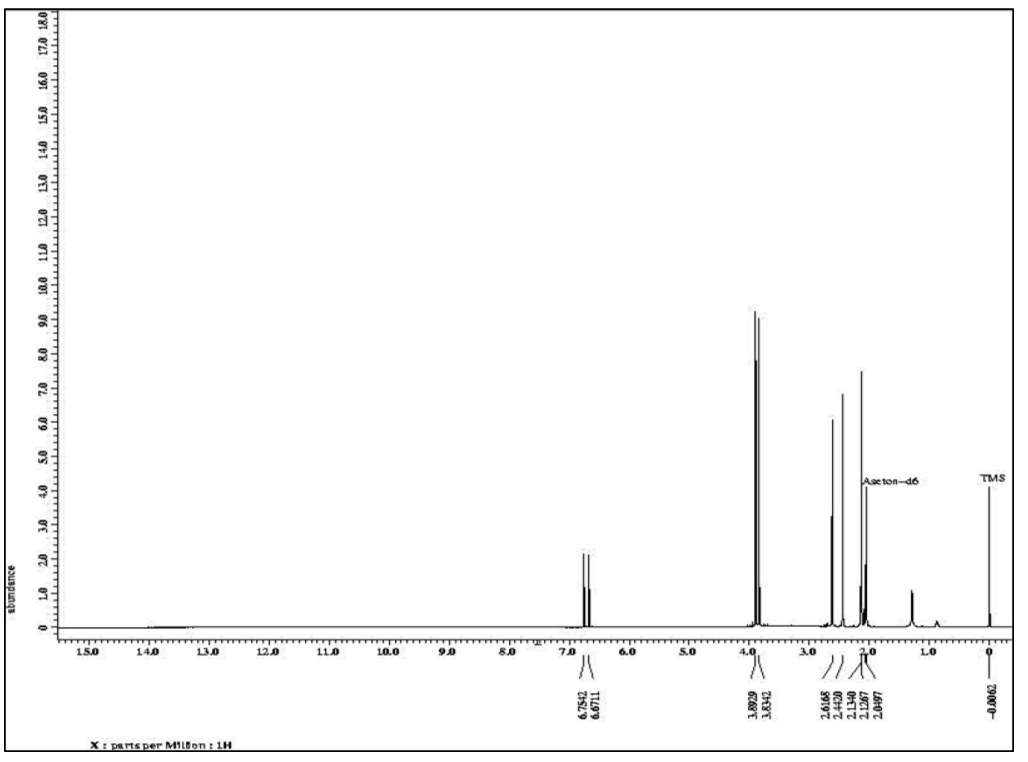

Figure 4. ${ }^{1} \mathrm{H}-\mathrm{NMR}$ spectrum data of compound isolate. 
Table 1. ${ }^{1} \mathrm{H}-\mathrm{NMR}$ and ${ }^{13} \mathrm{C}-\mathrm{NMR}$ data for isolate and diffractic acid compound.

\begin{tabular}{|c|c|c|c|c|c|c|}
\hline \multirow{2}{*}{$\boldsymbol{H}$} & \multirow{2}{*}{$C$} & \multicolumn{2}{|c|}{ Isolate compound } & \multicolumn{2}{|c|}{ Diffractic acid $^{a}$} & \multirow{2}{*}{$\begin{array}{l}\text { HMBC isolate } \\
\text { compound }\end{array}$} \\
\hline & & $\delta_{H}(\mathrm{ppm})$ & $\delta_{C}(\mathrm{ppm})$ & $\delta_{H}(\mathrm{ppm})$ & $\delta_{C}(\mathrm{ppm})$ & \\
\hline & 1 & & 117.85 & & 119.7 & \\
\hline & 2 & & 157.89 & & 159.5 & \\
\hline & 3 & & 120.92 & & 116.1 & \\
\hline & 4 & & 160.92 & & 156.4 & \\
\hline \multirow[t]{3}{*}{ H-5 } & 5 & $6.75(\mathrm{~s})$ & 109.11 & $6,75(\mathrm{~s})$ & 108.4 & $4,3,9$ \\
\hline & 6 & & 136.05 & & 134.6 & \\
\hline & 7 & & 166.54 & & 165.5 & \\
\hline $\mathrm{H}-8$ & 8 & $2.12(\mathrm{~s})$ & 9.11 & $2.18(\mathrm{~s})$ & 8.8 & 2,4 \\
\hline \multirow[t]{5}{*}{ H-9 } & 9 & $2.44(\mathrm{~s})$ & 20.04 & $2.47(\mathrm{~s})$ & 19.5 & $1,5,6$ \\
\hline & $1^{1}$ & & 110.33 & & 116.5 & \\
\hline & $2^{1}$ & & 164.07 & & 161.7 & \\
\hline & $3^{1}$ & & 117.52 & & 111.0 & \\
\hline & $4^{1}$ & & 154.44 & & 152.4 & \\
\hline \multirow[t]{3}{*}{$\mathrm{H}-5^{1}$} & $5^{1}$ & $6.67(\mathrm{~s})$ & 117.18 & $6.67(\mathrm{~s})$ & 115.8 & $1^{1}, 3^{1}, 4^{1}, 9^{1}$ \\
\hline & $6^{1}$ & & 141.13 & & 139.3 & \\
\hline & $7^{1}$ & & 174.36 & & 173.4 & \\
\hline $\mathrm{H}-8^{1}$ & $8^{1}$ & $2.13(\mathrm{~s})$ & 9.36 & $2.18(\mathrm{~s})$ & 9.0 & $2^{1}, 3^{1}, 4^{1}$ \\
\hline $\mathrm{H}-9^{1}$ & $9^{1}$ & $2.61(\mathrm{~s})$ & 24.01 & $2.61(\mathrm{~s})$ & 23.0 & $1^{1}, 5^{1}, 6^{1}$ \\
\hline $2-\mathrm{OCH}_{3}$ & $2-\mathrm{OCH}_{3}$ & $3.83(\mathrm{~s})$ & 62.39 & $3.85(\mathrm{~s})$ & 61.7 & 2 \\
\hline $4-\mathrm{OCH}_{3}$ & $4-\mathrm{OCH}_{3}$ & $3.89(\mathrm{~s})$ & 56.25 & $3.87(\mathrm{~s})$ & 55.7 & 4 \\
\hline $2^{1}-\mathrm{OH}$ & & & & $11.7(\mathrm{~s})$ & & \\
\hline
\end{tabular}

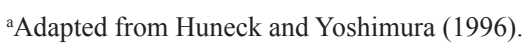

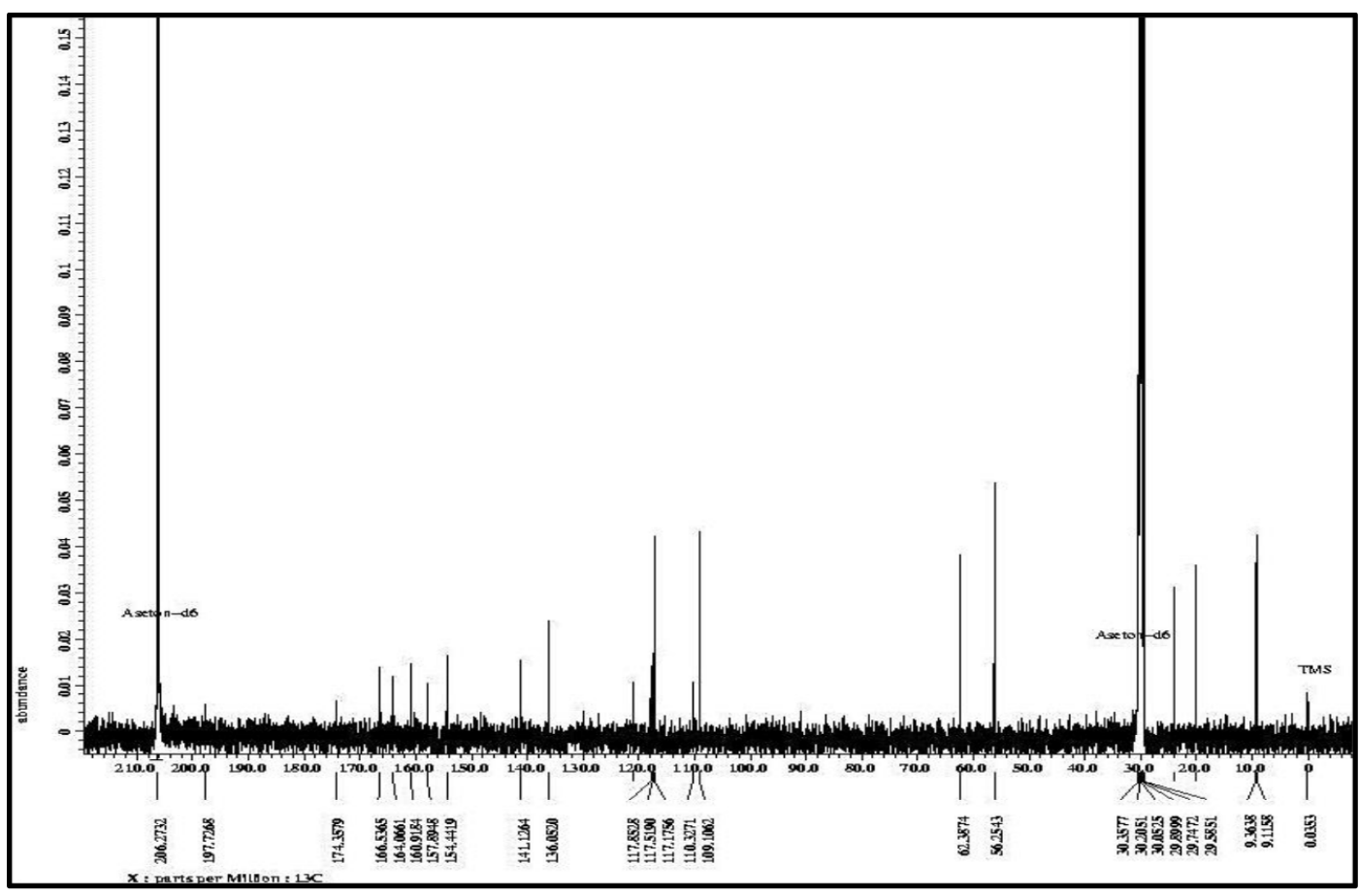

Figure 5. ${ }^{13} \mathrm{C}-\mathrm{NMR}$ spectrum data of compound isolate. 

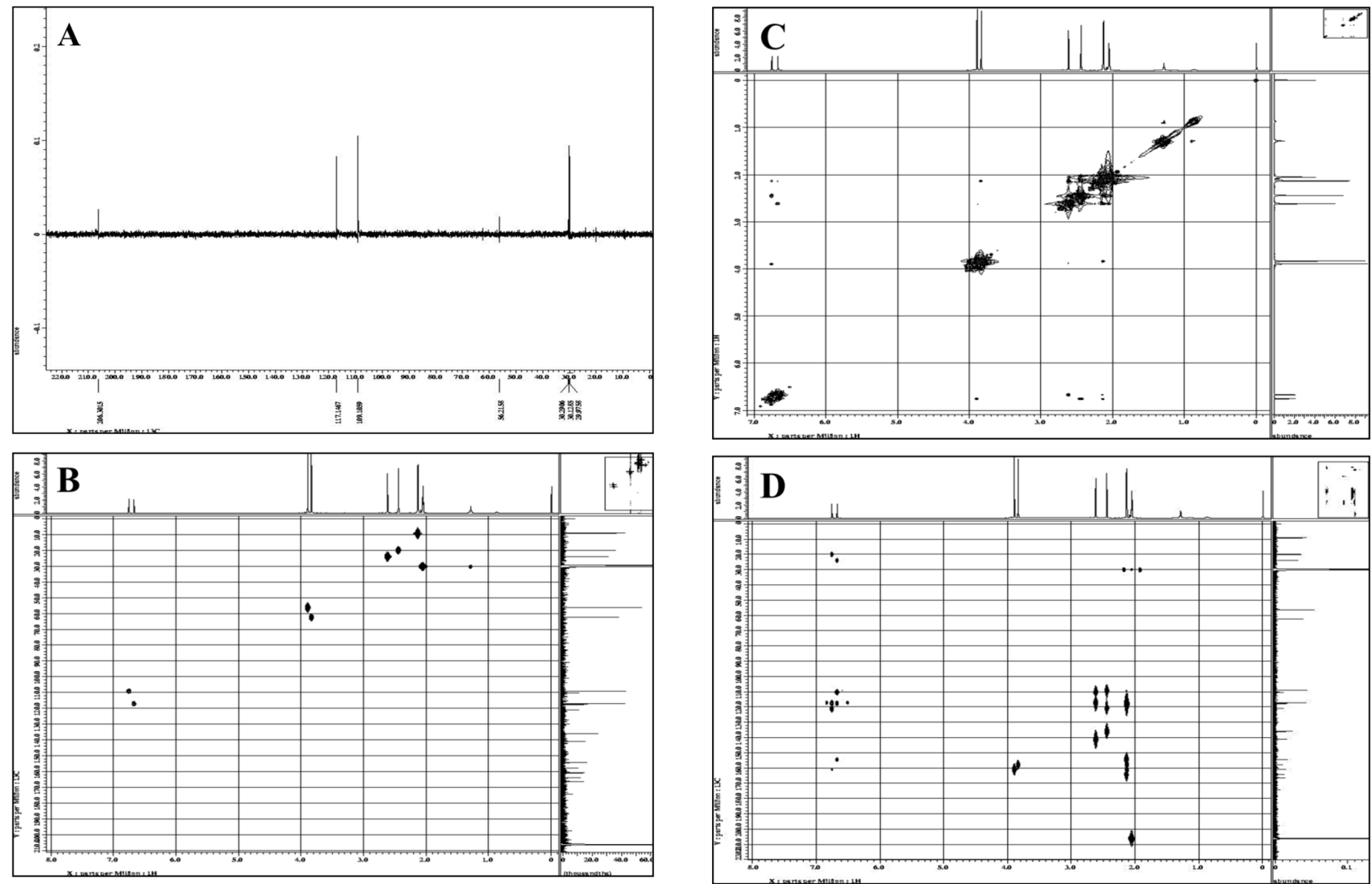

Figure 6. NMR-two-dimensional spectrum of (A) DEPT, (B) HMQC, (C) COSY, and (D) HMBC.

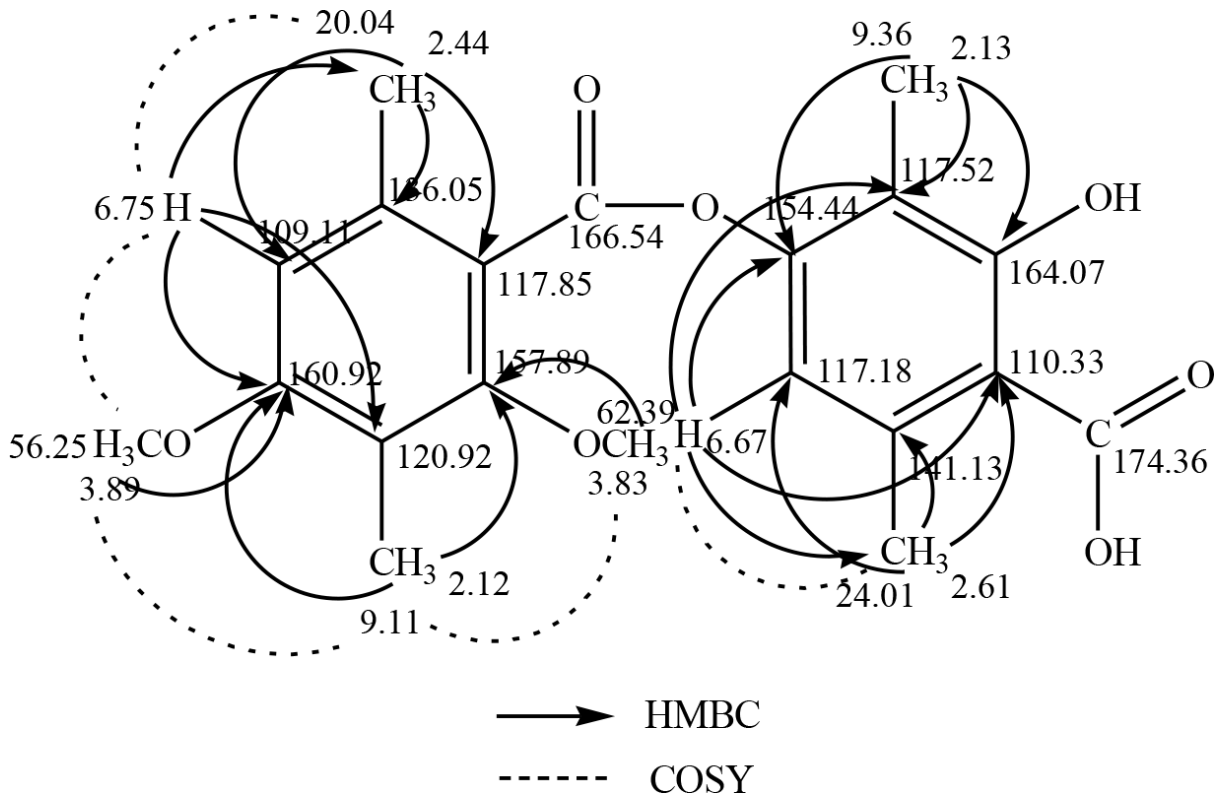

Figure 7. HMBC and COSY analysis of isolate compounds. 


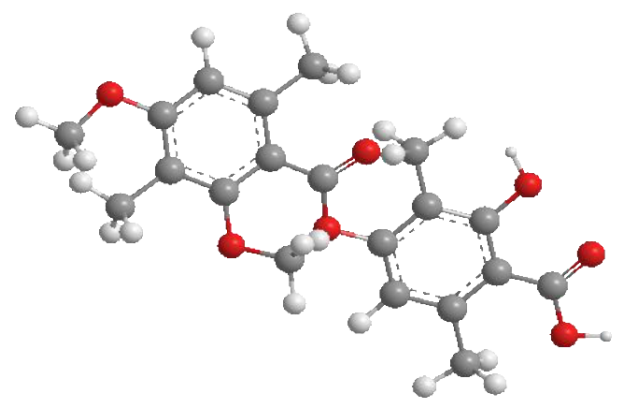<smiles>COc1c(C)c(C)c(C(=O)Oc2c(C)c(C)c(C)c(C(=O)O)c2C)c(C)c1O</smiles>

Figure 8. Structure of diffractic acid compound.

A

Bacteria: Sthapylococcus aureus

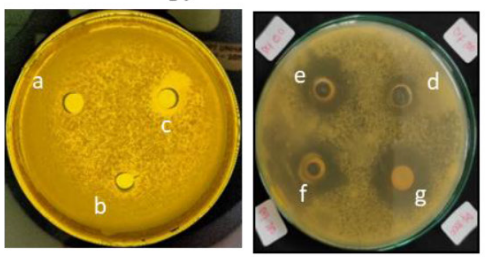

Bacteria: Escherichia coli

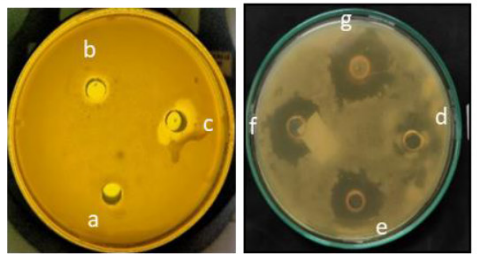

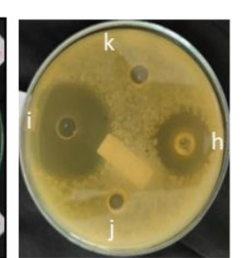

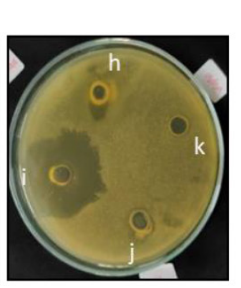

B

Bacteria: Sthapylococcus aureus

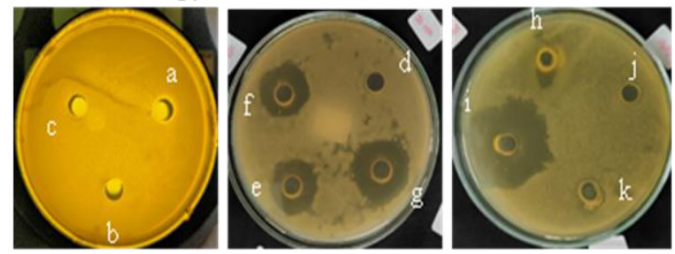

Bacteria: Escherichia coli
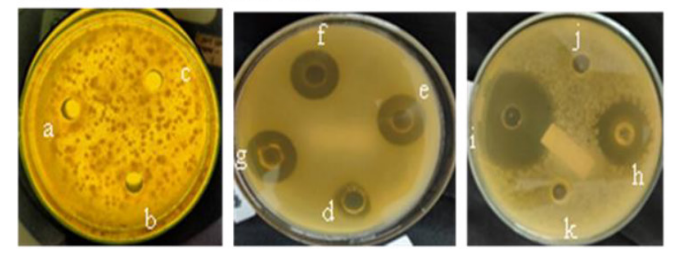

Figure 9. Inhibition zone of (A) acetone extract of lichen U. blepharea Motyka and (B) diffractic acid compound. (a) $12 \mathrm{ppm}$, (b) $25 \mathrm{ppm}$, (c) $50 \mathrm{ppm}$, (d) $100 \mathrm{ppm}$, (e) $500 \mathrm{ppm}$, (f) $750 \mathrm{ppm}$, (g) 1,000 ppm, (h) amoxicillin 1,000 ppm, (i) chloramphenicol $1,000 \mathrm{ppm},(\mathrm{j})$ water, and $(\mathrm{k})$ acetone.

$=117.18)$, and $\mathrm{C}-4^{1}\left(\delta_{\mathrm{C}}=154.44\right)$. The proton $\mathrm{H}-9^{1}$ is at $\delta_{\mathrm{H}}=2.61$ with carbons $\mathrm{C}-1^{1}\left(\delta_{\mathrm{C}}=110.33\right), \mathrm{C}-3^{1}\left(\delta_{\mathrm{C}}=117.52\right)$, and C- $6^{1}\left(\delta_{\mathrm{C}}=\right.$ 141.13). Proton 2- $\mathrm{OCH}_{3}$ in chemical shift $\delta_{\mathrm{H}}=3.83$ correlated with carbon $\mathrm{C}-2\left(\delta_{\mathrm{C}}=157.89\right)$. Proton $4-\mathrm{OCH}_{3}$ in chemical shift $\delta_{\mathrm{H}}=$ 3.89 correlated with carbon C-4 $\left(\delta_{\mathrm{C}}=160.92\right)$. HMBC and COSY analysis of isolate compounds can be seen in Figure 7.

Based on the measurement results of ${ }^{1} \mathrm{H}-\mathrm{NMR},{ }^{13} \mathrm{C}-\mathrm{NMR}$, FTIR, UV-Vis, and LC-MS, the structure of the compound isolate is diffractic acid with the molecular structure formula $\mathrm{C}_{20} \mathrm{H}_{22} \mathrm{O}_{7}$. Diffractic acid compound is a single compound that has a hydroxyl $(\mathrm{OH})$, methyl $\left(-\mathrm{CH}_{3}\right)$, carbonyl $(\mathrm{CO})$, and oxygen bridge (R-O-R) group connecting two benzenes (Fig. 8). Diffractic acid has been found in lichen Usnea diffracta Vain (Huneck and Yoshimura, 1996), U. Heterodea muelleri (Hampe) Nyl., Stictaceae (Hager et al., 2008), U. longissima (Culberson, 1969), and Usnea sp. (Maulidiyah et al., 2021a). Based on the literature search, this compound has never been found in U. blepharea Motyka.

\section{Antibacterial activity test}

Antibacterial activity testing aims to determine the sensitivity of bacteria to the test sample (Murugesan, 2020; Sisodia et al., 2013). In the test, we specifically compared the activity of diffractic acid to amoxicillin and chloramphenicol. The two compounds were used as a comparison, with the concentration
$1,000 \mathrm{ppm}$. In addition to being commonly used in testing the activity of control compounds, the selection of concentrations of both amoxicillin and chloramphenicol is based on the standard dose of the drug and the repetition of daily doses, where the standard doses for both are 500 and $400 \mathrm{mg}$, respectively (Rocha et al., 2019; Yuxuan et al., 2019). The sensitivity of bacteria to the test sample is indicated by the formation of a clear zone around the well hole which indicates an area of inhibition of bacterial growth. The results of the inhibition zone measurement of the test sample against $S$. aureus and E. coli bacteria are shown in Figure 9A and B.

Based on Table 2, the largest diameter of the zone of inhibition was shown in the acetone extract of lichen U. blepharea Motyka at a concentration of $1,000 \mathrm{ppm}$ against $S$. aureus bacteria which was $21.25 \mathrm{~mm}$ (very strongly) and $E$. coli bacteria which was $17 \mathrm{~mm}$ (strongly). The diffractic acid compound also actively inhibited the growth of $S$. aureus bacteria at a concentration of $1,000 \mathrm{ppm}$ with inhibition zones of $17.25 \mathrm{~mm}$ (very strongly) and inhibited the growth of $E$. coli bacteria at a concentration of 1,000 ppm with inhibition zones of $12.75 \mathrm{~mm}$ (strongly). Although in general the activity of antibiotic compounds (amoxicillin and chloramphenicol) is better than diffractic acid, with a larger diameter of inhibition zone, the category shows a good potential of diffractic acid as a new antibiotic candidate. 
Table 2. Antibacterial test results of acetone extract and diffractic acid from lichen U. blepharea Motyka.

\begin{tabular}{|c|c|c|c|}
\hline Bacteria & Sample & $\begin{array}{c}\text { Inhibition zone } \\
(\mathbf{m m})\end{array}$ & Category \\
\hline \multirow{18}{*}{$\begin{array}{c}\text { S. aureus } \\
\text { (Gram positive) }\end{array}$} & Amoxicillin 1,000 ppm (+) & 22 & Very strong \\
\hline & Chloramphenicol $1,000 \mathrm{ppm}(+)$ & 30.75 & Very strong \\
\hline & Acetone $(-)$ & 0 & Not active \\
\hline & Water $(-)$ & 0 & Not active \\
\hline & Acetone extract $12 \mathrm{ppm}$ & 0 & Not active \\
\hline & Acetone extract $25 \mathrm{ppm}$ & 2.25 & Weak \\
\hline & Acetone extract $50 \mathrm{ppm}$ & 6.5 & Moderate \\
\hline & Acetone extract $100 \mathrm{ppm}$ & 12.75 & Strong \\
\hline & Acetone extract $500 \mathrm{ppm}$ & 17 & Strong \\
\hline & Acetone extract $750 \mathrm{ppm}$ & 20 & Very strong \\
\hline & Acetone extract $1,000 \mathrm{ppm}$ & 21.25 & Very strong \\
\hline & Diffractic acid 12 ppm & 0 & Not active \\
\hline & Diffractic acid $25 \mathrm{ppm}$ & 0 & Not active \\
\hline & Diffractic acid 50 ppm & 2.5 & Weak \\
\hline & Diffractic acid $100 \mathrm{ppm}$ & 7.5 & Moderate \\
\hline & Diffractic acid $500 \mathrm{ppm}$ & 13.27 & Strong \\
\hline & Diffractic acid $750 \mathrm{ppm}$ & 14.27 & Very strong \\
\hline & Diffractic acid 1,000 ppm & 17.75 & Very strong \\
\hline \multirow{18}{*}{$\begin{array}{c}\text { E. coli } \\
\text { (Gram negative) }\end{array}$} & Amoxicillin 1,000 ppm (+) & 15.75 & Strong \\
\hline & Chloramphenicol $1,000 \mathrm{ppm}(+)$ & 31.25 & Very strong \\
\hline & Acetone (-) & 0 & Not active \\
\hline & Water $(-)$ & 0 & Not active \\
\hline & Acetone extract $12 \mathrm{ppm}$ & 0 & Not active \\
\hline & Acetone extract $25 \mathrm{ppm}$ & 1.25 & Weak \\
\hline & Acetone extract $50 \mathrm{ppm}$ & 6.75 & Moderate \\
\hline & Acetone extract $100 \mathrm{ppm}$ & 9 & Moderate \\
\hline & Acetone extract 500 ppm & 12.5 & Strong \\
\hline & Acetone extract $750 \mathrm{ppm}$ & 15.25 & Strong \\
\hline & Acetone extract $1,000 \mathrm{ppm}$ & 17 & Strong \\
\hline & Diffractic acid 12 ppm & 0 & Not active \\
\hline & Diffractic acid $25 \mathrm{ppm}$ & 0 & Not active \\
\hline & Diffractic acid $50 \mathrm{ppm}$ & 1.5 & Weak \\
\hline & Diffractic acid 100 ppm & 5.2 & Moderate \\
\hline & Diffractic acid 500 ppm & 11 & Strong \\
\hline & Diffractic acid 750 ppm & 11 & Strong \\
\hline & Diffractic acid $1,000 \mathrm{ppm}$ & 12.75 & Strong \\
\hline
\end{tabular}

The diameter of the inhibition zone formed increases with an increasing concentration of the test sample. This is supported by a research report from Maulidiyah et al. (2016b), Cankilic et al. (2017) and Nugraha et al. (2019) where the chloroform extract of lichen $U$. blepharea Motyka was found to increase with increasing concentration. The minimum concentration of each test sample used shows no inhibitory activity. The minimum inhibitory concentration has been shown in this test. The control of acetone and water did not show any inhibition zone formed. This proves that the presence of acetone in the extract of lichen $U$. blepharea Motyka did not affect the diameter size of the inhibition zone of the two tested bacteria. The water used as negative control also did not show the inhibition zone activity of the two test bacteria added to the antibiotic. The $\mathrm{OH}$ group in diffractic acid can damage the tertiary structure of the protein on the bacterial cell membrane by forming hydrogen bonds with the $\mathrm{N}$ and $\mathrm{H}$ atoms in the amino acids that make up the protein (Fig. 10). Furthermore, the damage to the cell membrane results in damage to the transport route for the entry and exit of substances into the cell (Shrestha et al., 2016).

The testing antibacterial activity of the acetone extract lichen $U$. blepharea Motyka and diffractic acid compounds against $E$. coli and $S$. aureus bacteria showed a difference in the test results on the average diameter of the resulting inhibition zone. Escherichia coli bacteria have an average inhibition zone diameter smaller than 


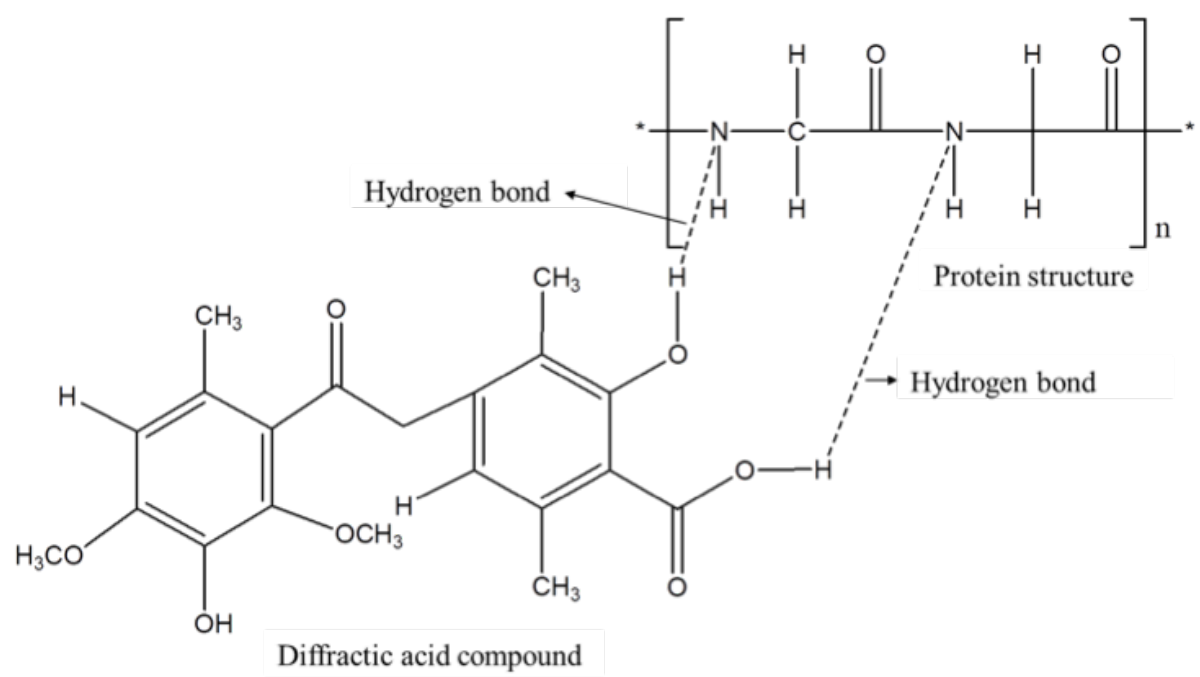

Figure 10. Hydrogen bond formation mechanism in diffractic acid compounds.

the average inhibition zone diameter in $S$. aureus bacteria. This is due to differences in the types between the two bacteria which affect the differences in the structure of the cell wall, plasma membrane, and the pathogenicity of the two bacteria. Escherichia coli bacteria belonging to Gram-negative bacteria have a complex cell wall structure (Maulidiyah et al., 2018; Sarowska et al., 2019). The structure of the Gram-negative cell wall, namely the outer layer, consists of lipoproteins, the middle layer is thin peptidoglycan, and the inner layer is thick lipopolysaccharides (Horvatic et al., 2019). This is thought to have caused the activity of the test sample against $E$. coli to be weaker than against the Gram-positive $S$. aureus.

\section{CONCLUSION}

The secondary metabolite isolated from $U$. blepharea Motyka is a diffractic acid compound with the molecular formula $\mathrm{C}_{20} \mathrm{H}_{22} \mathrm{O}_{7}$. Antibacterial bioactivity test showed that the diffractic acid compound actively inhibited (very strongly) the growth of $S$. aureus bacteria at concentrations of 750 and $1,000 \mathrm{ppm}$ with inhibition zones of 14.27 and $17.25 \mathrm{~mm}$, respectively. In addition, E. coli bacteria were also actively inhibited (strongly) at concentrations of 750 and $1,000 \mathrm{ppm}$ at 11.00 and $12.75 \mathrm{~mm}$, respectively. This study is very interestingly the latest reference source for natural compounds, especially the lichen $U$. blepharea Motyka, because there have been no reports related to diffractic acid compounds found from this lichen genus and also its activity as a strong antibacterial. Positive results from antibacterial testing of $S$. aureus and E. coli. are very important for the development of the pharmaceutical field in the future, especially in the development of diarrhea and antibiotic drugs.

\section{ACKNOWLEDGMENTS}

The authors acknowledge the financial support from the Ministry of Research and Technology/National Research and Innovation Agency (KEMRISTEK/BRIN), the Republic of Indonesia, under Basic Research 2021 Grant no. 199/SP2H/LT/DRPM/2021.

\section{AUTHOR CONTRIBUTIONS}

All authors made substantial contributions to conception and design, acquisition of data, or analysis and interpretation of data; took part in drafting the article or revising it critically for important intellectual content; agreed to submit to the current journal; gave final approval of the version to be published; and agree to be accountable for all aspects of the work. All the authors are eligible to be an author as per the international committee of medical journal editors (ICMJE) requirements/guidelines.

\section{CONFLICTS OF INTEREST}

The authors report no financial or any other conflicts of interest in this work.

\section{ETHICAL APPROVALS}

This study does not involve experiments on animals or human subjects.

\section{PUBLISHER'S NOTE}

This journal remains neutral with regard to jurisdictional claims in published institutional affiliation.

\section{REFERENCES}

Abid AR, Marciniak B, Pedzinski T, Shahid M. Photo-stability and photo-sensitizing characterization of selected sunscreens' ingredients. J Photochem Photobiol A, 2017; 332:241-50

Bayir Y, Odabasoglu F, Cakir A, Aslan A, Suleyman H, Halici M, Kazaz C. The inhibition of gastric mucosal lesion, oxidative stress and neutrophil-infiltration in rats by the lichen constituent diffractaic acid. Phytomedicine, 2006; 13(8):584-90.

Belay A, Gholap AV. Characterization and determination of chlorogenic acids (CGA) in coffee beans by UV-Vis spectroscopy. Afr J Pure Appl Chem, 2009; 3(11):34-240.

Cankilic MY, Sariozlu NY, Candan M, Tay F. Screening of antibacterial, antituberculosis and antifungal effects of lichen usnea florida and its thamnolic acid constituent. Biomed Res, 2017; 28:3108-13.

Culberson CF. Chemical and botanical guide to lichen products. North Carolina Press, Chapel Hill, NC, pp 85-93, 1969.

Dini I, Maryono A, Sitti H. Phytochemical analysis and antimalarial activity of Usnea sp. from south Sulawesi against $P$. falciparum. Int J Curr Microbiol Appl Sci, 2017; 6(9):1653-60.

Hager A, Brunauer G, Turk R, Stocker-Worgotter E. Production and bioactivity of common lichen metabolites as exemplified by Heterodea muelleri (Hampe) Nyl. J Chem Ecol, 2008; 34(2):113-20. 
Horvatic A, Guillemin N, Kaab H, McKeegan D, O'Reilly E, Bain M, Kules J, Eckersall PD. Quantitative proteomics using tandem mass tags in relation to the acute phase protein response in chicken challenged with Escherichia coli lipopolysaccharide endotoxin. J Proteomics, 2019; 192:64-77.

Huneck S, Yoshimura I. Identification of lichen substances. In: Identification of lichen substances. Springer, Berlin, Germany, pp 11-123, 1996.

Karve SS, Pradhan S, Ward DV, Weiss AA. Intestinal organoids model human responses to infection by commensal and Shiga toxin producing Escherichia coli. PLoS One, 2017; 12(6):e0178966.

Kosanic M, Rankovic B. Lichen secondary metabolites: bioactive properties and pharmaceutical potential. Lichen Second Metab Bioact Prop Pharm Potential, 2015; 202:1-202.

Lumbsch HT. Taxonomic use of metabolic data in lichenforming fungi. In: Chemical fungal taxonomy. CRC Press, Boca Raton, FL, pp 345-87, 2020.

Maulidiyah, Azis T, Sabarwati SH, Nurdin M. Isolation and identification of (-) usnic acid compound from lichen Usnea sp. and its cytotoxic activity on mur. J Ilmu Kefarmasian Indones, 2015a; 13(1):40-4.

Maulidiyah M, Cahyana AH, Suwarso WP. A new phenolic compound from acetone extract of lichen Usnea flexuosa Tayl. Indones J Chem, 2011; 11(3):290-4.

Maulidiyah M, Cahyana AH, Suwarso WP, Nurdin M. Isolation and structure elucidation of eumitrin A1 from lichen Usnea blepharea Motyka and its cytotoxic activity. Int J PharmTech Res, 2015b; 8(4):782-9.

Maulidiyah M, Darmawan A, Ahmad E, Musdalifah A, Wibowo D, Salim LOA, Arham Z, Mustapa F, Nurdin IFA, Nurdin M. Antioxidant activity-guided isolation of usnic acid and diffractaic acid compounds from lichen genus Usnea sp. J Appl Pharm Sci, 2021a; 11(02):75-83.

Maulidiyah M, Darmawan A, Hasan A, Wibowo D, Salim LOA, Ansharullah A, Mustapa F, Nurdin IFA, Nurdin M. Isolation, structure elucidation, and antidiabetic test of vicanicin compound from lichen Teloschistes flavicans. J Appl Pharm Sci, 2020a; 10(11):1-9.

Maulidiyah M, Darmawan A, Usman U, Musdalifah A, Ode L, Salim A, Nurdin M. Antioxidant activity of secondary metabolite compounds from lichen Teloschistes flavicans. Biointerface Res Appl Chem, 2021b; 11(6):13878-84.

Maulidiyah M, Hasan A, Irna WO, Farah I, Nurdin A, Kusmalawati T, Watoni AH, Azis T, Darmawan A. Antifungal potential against Aspergillus flavus: secondary metabolite compound from unique organism of lichen Teloschistes flavicans. Int Res J Pharm, 2018; 9(8):1-6.

Maulidiyah M, Imran I, Muntu W, Nurdin M. Secondary metabolites identification from lichen Usnea longissima Ach.: bioactivity test of antibacterial. Int J Appl Chem, 2016a; 12(3):347-57.

Maulidiyah M, Sabarwati SH, Harjuliarto R, Watoni AH, Nurdin M. Antibacterial activity of usnic acid from Usnea longissima Ach. Pak J Pharm Sci, 2020b; 3(4):1631-9.

Maulidiyah M, Sabarwati SH, Safutra E, Nurdin ME, Nurdin, M. Atranorin secondary metabolite from lichen Usnea sp. and its antibacterial activity. Int J Pharma Bio Sci, 2016b; 7(3):159-69.

Mitrovic T, Stamenkovic S, Cvetkovic V, Tosic S, Stankovic M, Radojevic I, Stefanovic O, Comic L, Dacic D, Curcic M. Antioxidant, antimicrobial and antiproliferative activities of five lichen species. Int J Mol Sci, 2011; 12(8):5428-48.

Murugesan P. Phytochemical analysis and antimicrobial activity of edible lichen. J Drug Deliv Ther, 2020; 10:102-4.

Nugraha AS, Pratoko DK, Damayanti YD, Lestari ND, Laksono TA, Addy HS, Untari LF, Kusumawardani B, Wangchuk P. Antibacterial and anticancer activities of nine lichens of Indonesian Java Island. J Biol Act Prod Nat, 2019; 9(1):39-46.

Oh JM, Kim YJ, Gang HS, Han J, Ha HH, Kim H. Antimicrobial activity of divaricatic acid isolated from the lichen Evernia mesomorpha against methicillin-resistant Staphylococcus aureus. Molecules, 2018; 23(12):3068.

Pamenta AFA, Azis T, Watoni AH, Natsir M, Ansharullah, Adiba IF, Dermawan A, Nurdin M, Maulidiyah. Antimalarial activity of lichen
Usnea longissima. In AIP Conference Proceedings. AIP Publishing LLC, Melville, NY, p 20017, 2020

Rankovic B, Kosanic M. Lichens as a potential source of bioactive secondary metabolites. In: Lichen secondary metabolites. Springer, Cham, Switzerland, pp 1-29, 2019.

Rankovic B, Kosanic M, Stanojkovic T, Vasiljevic P, Manojlovic N. Biological activities of Toninia candida and Usnea barbata together with their norstictic acid and usnic acid constituents. Int J Mol Sci, 2012; 13(11):14707-22.

Rocha MBS, Nucci GD, Lemos FN, Babadopulos RFDAL, Rohleder AVP, Fechine FV, Antunes NJ, Mendes GD, Nascimento DFD, Moraes MOD, Moraes MEAD. Impact of bariatric surgery on the pharmacokinetics parameters of amoxicillin. Obes Surg, 2019; 29(3): 917-27.

Sarowska J, Futoma-Koloch B, Jama-Kmiecik A, Frej-Madrzak M, Ksiazczyk M, Bugla-Ploskonska G, Choroszy-Krol I. Virulence factors, prevalence and potential transmission of extraintestinal pathogenic Escherichia coli isolated from different sources: recent reports. Gut Pathog, 2019; 11:1-6.

Sasidharan NK, Sreekala SR, Lakshmanan R, Jacob J, Amma S, Nair DKB, Nambisan B. Protolichesterinic acid: a prominent broad spectrum antimicrobial compound from the lichen Usnea albopunctata. Int J Antibiot, 2014; 2014:1-6.

Sepahvand A, Studzinska-Sroka E, Ramak P, Karimian V. Usnea sp.: antimicrobial potential, bioactive compounds, ethnopharmacological uses and other pharmacological properties; a review article. J Ethnopharmacol, 2020; 268:113656.

Shrestha G, Clair LLS. Lichens: a promising source of antibiotic and anticancer drugs. Phytochem Rev, 2013; 12(1):229-44.

Shrestha G, Thompson A, Robison R, St Clair LL. Letharia vulpina, a vulpinic acid containing lichen, targets cell membrane and cell division processes in methicillin-resistant Staphylococcus aureus. Pharm Biol, 2016; 54:413-8.

Siddiqi KS, Rashid M, Rahman A, Husen A, Rehman S. Biogenic fabrication and characterization of silver nanoparticles using aqueousethanolic extract of lichen (Usnea longissima) and their antimicrobial activity. Biomater Res, 2018; 22(1):1-9.

Sisodia R, Verma S, Rani A, Dureja P. Antibacterial and antioxidant activity of lichen species Ramalina roesleri. Nat Prod Res, $2013 ; 27(23): 2235-9$

Sudarwanti CS, Imran I, Yanti NA, Musdalifah A, Nurdin M, Maulidiyah M. Antimicrobial activity of acetone extract and usnic acid constituent of lichen Usnea longissima (Ach.). Int Res J Pharm, 2018; 9(7):89-98.

Yu X, Guo Q, Su G, Yang A, Hu Z, Qu C, Wan Z, Li R, Tu P, Chai $X$. Usnic acid derivatives with cytotoxic and antifungal activities from the lichen Usnea longissima. J Nat Prod, 2016; 79(5):1373-80.

Yuxuan Z, Peiyong G, Yanmei W, Xiaoyan Z, Meixian W, Simin Y, Yinshi S, Jun D, Haitao, S. Evaluation of the subtle effects and oxidative stress response of chloramphenicol, thiamphenicol, and florfenicol in Daphnia magna. Environ Toxicol Chem, 2019; 38(3):575-84.

Zugic A, Jeremic I, Isakovic A, Arsic I, Savic S, Tadic V. Evaluation of anticancer and antioxidant activity of a commercially available $\mathrm{CO}_{2}$ supercritical extract of old man's beard (Usnea barbata). PLoS One, 2016; 11(1):e0146342.

\section{How to cite this article:}

Maulidiyah M, Natsir M, Nazila W, Musdalifah A, Salim OA, Nurdin M. Isolation and antibacterial activity of diffractic acid compound from lichen Usnea blepharea Motyka. J Appl Pharm Sci, 2021; 11(11):121-130. 